ECONOMIC THEMES (2019) 57(1): 21-33

DOI 10.2478/ethemes-2019-0002

\title{
INNOVATED ALTMAN'S MODEL AS A PREDICTOR OF MALFUNCTIONING OF SMALL AND MEDIUM-SIZED BUSINESSES IN BOSNIA AND HERZEGOVINA
}

\author{
Selma Vidimlić \\ JP “Tržnica” Ltd. Zenica, Bosnia and Herzegovina \\ $\bowtie$ selmavidimlic@yahoo.com
}

UDC

Abstract: The research was conducted with the aim of finding a model that

$334.012 .63 /$.

64(497.6)

best predicts the financial success or failure of the company. On the sample of $392 \mathrm{SME}$ in Bosnia and Herzegovina, testing possibilities using the innovated Altman's model for prediction of financial difficulties of the enterprise was carried out. The financial statements from the end of the

Original year 2014 of these companies were reviewed. The sample was divided into

scientific two groups: companies that had blocked transaction accounts during 2015 and 2016 and those companies that did not have blocked transaction accounts during this period. Testing has shown that the Altman's model may, but with limited capability, be used to predict the disruption of small and medium-sized businesses in Bosnia and Herzegovina. The paper presents the facts that affect the business of SME in Bosnia and Herzegovina, and way they influence selection and, possibly, other predictors of non-business operations

Received: Keywords: prediction, SME, Altman's model, financial failure, business 03.05.2018 Accepted: 28.03.2019 distress, financial indicator.

JEL classification: M40, C80, G33

\section{Introduction}

The authors have noticed long ago that the proportion of individual items from financial indicators can point to certain difficulties in business operations. With this topic, the researchers first worked with large companies, however, as well as changing the way of doing business all over the world, so small and medium-sized enterprises became more and more important in research, so in the last two decades this issue has been adressed with particular attention. The aim is to find those 
financial indicators that are the best predictors of potential bad business operations in the next year, the next two or three years, by analysing the operations of small and medium-sized enterprises.

Only in the last few decades, more precisely since the first oil shock in 1973 and the second oil spill in 1978, SME has gained importance as a business segment. At that time, the understanding of the power of economic flows which prevailed was that only large enterprises were important for the growth and prosperity of the economic system, while SMEs were marginalized and did not attach great importance to them in the academic community. Investigations that related to the prospect of possible bankruptcy, liquidation or other forms of disturbance of financial stability of the enterprise concerned only large business systems, while analysis and studies SME were completely omitted. However, the crisis that came about after the above-mentioned oil shocks, and later that caused the decline in employment, the height and fall of the gross domestic product, have led the academic community and industry experts to research development of micro enterprises and SMEs. By holding the White House Conference on small businesses in 1980, a new era emerged in the concept of economic functioning, where the MSP segment played a huge role (Petković, 2010).

As in developed countries in the world, so in transitional countries, including the countries in the region, during the 1990s of the past century, the emphasis on studying and empowering the economy was transferred to SME. However, it should be noted that academic circles have now been struck by the view that a synergy between large enterprises and SMEs is needed for sound economic growth, as SMEs are often co-operatives of large enterprises.

\section{Review of previous resarch}

The first Beaver (1966) model found that three financial indicators were obtained from company financial reports, which were key to predicting financial failure of the company.

A few years later, Edmister (1972) used three-year average indicators for researchers.

Altman's (1977) Zeta model is the most significant, fundamental research, which is based on discriminatory analysis of financial indicators and which, with great probability, could account for bankruptcy of up to $96.2 \%$ during the first year. The model later changed, adapted to different branches of activity and size of the company. In 2008 was supplemented with qualitative information.

Logical regression was first applied by Ohlson (1980). He made three models. The first model predicte $\mathrm{d}$ bankruptcies within the first year of business after a forecast with a probability of $96.12 \%$, the second model predicted bankruptcy 
within two years with a probability of $95.55 \%$, and the third model had $92.84 \%$ confidence to predict bankruptcy within three years.

Kraliček's quick test, which, unlike the models mentioned above, is dynamic. It analyses the risk of financing, liquidity, profitability and success rate by a rating of 1 to 5 (Salkić, 2013).

During the first and second decades of the 21st century, many authors conducted a research into the possible disadvantages of small and medium-sized enterprises. Teti et al. (2012), Janer (2011), Jazdanfar and Nilsson (2008), Khanji (2010), Nur Adiana et al. (2014), Marom and Lussier (2014), Wellalage and Locke (2012), Mramor and Valenti (2003), Chancharat (2011), Ekes and Koloszar (2014), Mures-Quintana (2014)performed research in Italy, France, Sweden, Great Britain, Malaysia, Hungary, Spain, Israel, New Zealand, India, as well as many other authors in many other countries. They applied methods of a discriminatory analysis, logical regression, and neural networks, and with less or greater certainty detected the financial indicators that can best predict the failure of a business.

Similar studies have been carried out in the countries of the region by the authors of Šarlija and Jeger (2011), Pervan et al. (2011), Salkić (2013), Muminović et al. (2011), Vidimlić (2015), and concluded that methods of a discriminatory analysis and logical regression can be used with probability most commonly between $80 \%$ and $90 \%$.

Also, a large part of the paper makes a contribution by testing some of the already established models for predicting the company's financial disadvantage. The purpose of this, as well as similar testing of already existing models, is to find out whether these researches and conclusions come from these researches can still be applied to today's different markets and postulate business in changed markets.

\section{Altman's Model for predicting bankruptcy of an enterprise}

In 1968, Edvard Altman, in New York, defined the Z-score model for the first time in history, using discretionary analysis to detect those financial indicators that are the best predictors of bankruptcy. He viewed companies that were in bankruptcy, but at the same time had a control group of companies that did not dealt with bankruptcy. In total, 66 companies were found in the sample, half of which were bankruptcy proceedings, i.e. they had submitted applications for opening bankruptcy proceedings.

In his research, Altman used 22 financial indicators, which were used in financial analysis at that time. Using multiple discrimination analysis, out of the above 22 financial indicators, elimination procedures, there were up to 5 financial leaseholders, taken from the financial statements, which best predicted the insolvency of the enterprise as well as their strength.

First formula Altman used was presented in the following way: 
$Z=1,2 \times 1+1,4 \times 2+3,3 \times 3+0,6 \times 4+0,999 \times 5(1)$

Where is it

$\mathrm{X} 1=($ Working capital assets- Short-term liabilities $) /$ Total assets

$\mathrm{X} 2=$ Unallocated profit/Total assets

X3 $=$ Business Profit/Total Assets

$\mathrm{X} 4=$ Market capitalization/Book value of total liabilities

$\mathrm{X} 5=$ Sales revenue/Total assets

Altman found out that the possibility of companies going into bankruptcy was negligible and the results above this number were called a "safe zone". For results less than 1.80 the probability of bankruptcy is very pronounced, calling this area "unsafe". For results between 1.80 and 2.99, it has been found that there is a possibility that the company will bankrupt, and this fact that the potential stakeholders have to keep in mind. This zone was called the "gray" zone.

Altman's model was accurate in $72 \%$ of the prognosticate bankruptcy over the next two years.

The first model Altman had developed included companies listing on the stock market, so it could not be applied to other companies. For this reason, Altman developed another model, calling it the Z'-score model, where the book value of capital was used instead of market capitalization, and in factor X4 it was in relation to total liabilities.

Revised formula has been published:

$Z^{\prime}=0.717 \mathrm{X} 1+0.847 \mathrm{X} 2+3.107 \mathrm{X} 3+0.420 \mathrm{X} 4+0.998 \mathrm{X} 5$

For $Z^{\prime}$, greater than 2.9, it is considered that the "safe" zone, for $Z^{\prime}$ below 1.23 is considered to be "uncertain" zone and for $Z$ ' within these two numbers, the company is in a "gray" zone.

Since different financial coefficients have generally been different for different activities, in 2000, Altman developed a broader model to reduce the effects of industry on the model for non-performing companies, but suggested it was appropriate to assess the risk of insolvency among non-financial corporations, including manufacturing, emerging markets and unstable markets. (Keser, Radivojac, 2015, p. 250).

The model is set up:

$Z^{\prime \prime}=6.56 \mathrm{X} 1+3.26 \mathrm{X} 2+6.72 \mathrm{X} 3+1.05 \mathrm{X} 4$

where are they

$\mathrm{X} 1=$ Working capital/Total assets 


$$
\begin{aligned}
& \text { X2 }=\text { Retained earnings/Total assets } \\
& \text { X3 }=\text { Profit before Interest and Tax (EBIT)/Total Assets } \\
& \text { X4 }=\text { Book value of the company/Total liability }
\end{aligned}
$$

As a sign of business disturbance, this study, in the treated sample, examines the blockade of the SME transaction account for more than two months.

There are many similar definitions of liquidity and solvency in the literature. Even some authors do not make a clear distinction between these two terms. There is a view that the term solvency is broader than the term liquidity. Solvency could be defined as the company's ability to make long-term liabilities. In this context, liquidity would be defined as the company's ability to meet its maturity obligations. (Mikerevic, 2011).

However, according to the authors Proklin and Zima (2011), it is more appropriate to talk about liquidity of entrepreneurs rather than companies. In this connection, according to the same authors, "the liquidity of an entrepreneur is the ability of his/her non-cash assets to convert into a relatively short term and without cash losses". Analogously, "the entrepreneur's illiquidity is the inability of his noncash assets to be converted into cash in a relatively short time and without loss".

The same authors defined solvency as "the ability of an entrepreneur to settle all outstanding debts within their maturity". Insolvency is, in the same way, defined as "a situation in which an entrepreneur is unable to settle his/her due debts within their maturity by dispersive money".

The principle of liquidity is the principle of meeting the financial obligations in the agreed terms. The prerequisite for liquidity of an enterprise is the respect of compliance between inflows and financial resources and payment of outstanding liabilities. The company is illiquid if it is not able to pay its financial obligations in the agreed terms. One illicit enterprise can cause illiquidity and other companies that do business with it.

The solvency of an enterprise represents the ability of the company to make its obligations even when it is from the bankruptcy estate. Insolvency is a condition when the company's assets are less than its liabilities, which is most often the result of too large indebtedness of the enterprise (Mikerević, 2011).

\section{Limitations of research}

Each and every research involves few or more difficulties that have influenced the research process and even the research results with lower or greater intensity. Thus, in this research, there were certain difficulties and circumstances that were incorporated in the development of this paper. 
The biggest difficulty was completely operational and related to data collection, i.e. financial reports. Although the data that was used in this paper was public, however, it needed effort, and due to the large amount of required financial reports, and the withdrawal of funds.

Another difficulty we faced was the lack of data for individual companies when it comes to financial statements - the cash flow statement. Although the sample treated small and medium sized enterprises, since two of the three met criteria were both the combination of the number of employees and the amount of the assets, the level of income as a criterion for classification of the SME did not have to be met the sample also found companies that do not have a statutory obligation to produce a cash flow statement.

The third challenge was to check the block of transaction accounts of the companies that were in the sample. According to the Central Bank of Bosnia and Herzegovina, public insolvency companies are published monthly. However, the retroactive data was obtained in a way that each individual company from the sample carried out a separate check in the records, which took a lot of time but caused the possibility of mistakes. Considering the size of the sample, a possible error would not have a significant impact on the results of the research.

The firms that have been dealt with by this research are presented in financial reports for 2014 to update the issues, and for discussion, which should, as a rule, be as much as possible with current data.

The presence of the anomaly is apparent in relation to the average values, average, maximum and minimum values. Median is the size that divides the pattern into two equal parts. This means that it is between the medium and the minimum value, and between the medium and the maximum value, on some indicators and by $50 \%$ of the sample size. Another type of anomaly is the presence of a greater number of zero or very low values. High degree of classification accuracy arises because of extreme values.

\section{An exploratory sample}

As a sample for this research, we used companies belonging to the Zenica-Doboj Canton, within the Federation of Bosnia and Herzegovina, the Republic of Bosnia and Herzegovina. In this region, about 3500 companies are registered. Out of above mentioned number of companies, all companies with revenues of more than two million convertible marks, property worth more than one million convertible marks, employing more than ten workers, were taken into consideration. In this way, all enterprises in one region are covered, regardless of their activity. The Zenica-Doboj Canton as a stratum was chosen as appropriate due to the author's scope. In this way, it is also possible to have a second check of credibility as well as a comparison with the author's earlier observations. 
Although the businesses of different industries are middle-sized, the pool is of industrial character, so the activities are predominantly manufacturing and trading.

The sample consists of two groups of firms; the first group, out of 70 companies, recorded the duration of the blockade in days and the other group, out of 322 firms, for which there was no blockade.

In the determination of the sample size, the last method, the method of industrial standards, was chosen from the methods used (the intuitive method, the statistical precision method, the cost constraints method and the industrial standard methods), because it is "based on certain standards that were formed on the basis of previous experience and serve as experiential rules "(Soldić-Aleksić and Chroneos Krasavac, 2009, p.16). Since the sample is random and stratified, and for this reason the industrial standard method is chosen as appropriate.

The sample is random, stratified. Namely, the basic set is divided geographically, by cantons, within the state of Bosnia and Herzegovina. The Zenica-Doboj Canton was selected as appropriate, and the SME from the mentioned Canton, which is treated in this research, is selected by random selection method from the AFIP database from which the financial statements will be downloaded for the SME balance sheets, balance of payments and cash flow statements for the year 2012 . Considering that in the Federation of Bosnia and Herzegovina small companies are not legally obliged to produce a cash flow statement, the sample will include companies with assets over 1 million,convertibile marks (KM) annual income over two million KM, and the number of employees over ten, i.e. belonging to a group of medium enterprises.

\section{Testing the innovated Altman's model}

Using data from financial statements and applying them to the innovated Altman's model, we come up with the following results.

Table 1.Testing Altman's model

\begin{tabular}{||l|c|c|c|c||}
\hline \hline Altman's model & $\mathrm{X} 1$ & $\mathrm{X} 2$ & $\mathrm{X} 3$ & $\mathrm{X} 4$ \\
\hline Blocked firms & & & & \\
\hline Maximum & 0,887623 & 0,805920 & 0,805920 & 15,33568 \\
\hline Minimum & $-0,856825$ & $-0,280188$ & $-0,280188$ & 0,00000 \\
\hline Span & 1,744448 & 1,086108 & 1,086108 & 15,33568 \\
\hline Average & $-0,074810$ & 0,023907 & 0,023907 & 1,67424 \\
\hline Standard deviation & 0,333316 & 0,130474 & 0,130474 & 3,14511 \\
\hline Median & $-0,057545$ & 0,007871 & 0,007871 & 0,49636 \\
\hline \hline
\end{tabular}




\begin{tabular}{|l|c|c|c|c||}
\hline Unbloced firms & & & & \\
\hline Maximum & 0,88189 & 1,00955 & 0,98272 & 119,39932 \\
\hline Minimum & $-0,91150$ & 0,00000 & $-0,23451$ & 0,00000 \\
\hline Span & 1,79339 & 1,00955 & 1,21723 & 119,39932 \\
\hline Average & 0,15567 & 0,28114 & 0,06448 & 4,12878 \\
\hline Standard deviation & 0,27771 & 0,24733 & 0,11885 & 11,86579 \\
\hline Median & 0,15164 & 0,22494 & 0,04389 & 1,17013 \\
\hline
\end{tabular}

Source: Author's calculation

In this case, the ranges for size $\mathrm{X} 4$ are noticeably large for both groups.

\section{Assessment of the Altman model's eligibility}

The following Table 2 is an overview of the frequency of classification by the theoretical model.

Table 2: Assessment of Altman's model eligibility

\begin{tabular}{|l|l|l|l||}
\hline & Gr1 & Gr2 & \\
\hline Mark 0 & $35(50,00 \%)$ & $61(18,94 \%)$ & $\mathbf{9 6}$ \\
\hline Mark 1 & $14(20,00 \%)$ & $63(19,57 \%)$ & $\mathbf{7 7}$ \\
\hline Mark 2 & $21(30,00 \%)$ & $198(61,49 \%)$ & $\mathbf{2 1 9}$ \\
\hline & $\mathbf{7 0}$ & $\mathbf{3 2 2}$ & $\mathbf{3 9 2}$ \\
\hline
\end{tabular}

Source: Author's calculation

Gr1 is for blocked and Gr2 for unblocked companies. Grades 0,1 and 2 were obtained by rating scale for this model. The testing showed that the innovated Altman's model for $50 \%$ blocked companies correctly predicted poor business ( $\mathrm{Gr} 1$, Mark 0). For $61.49 \%$ unblocked companies (Gr2, Mark 2) correctly predicted good business, and 19.57\% unblocked companies (Gr2, Mark 1) predicted a "gray" zone.

\section{Discussion}

A few facts are characteristic of business in transition countries, which affects the ability to use this model. Countries in transition are less developed than in the West, where they are usually models for assessing business continuity and emerging, including Altman's innovated model. Thus, we have the situation that small and medium-sized enterprises in transition countries, by their volume of business, actually earn in the ranks of micro companies from the countries of the developed West. This prevents the use of the same tools. Micro enterprises have 
different characteristics in relation to small and medium-sized enterprises. This fact supports the claim that models for assessing business continuity in developed countries have less predictive power in transition countries.

Another characteristic is the fulfillment of financial obligations. The poorer business entities, who are late in fulfilling their financial obligations, are quickly expelled from the market in developed countries. In transitional countries this is not the case. The slowness of paying obligations is often regarded as the usual way of doing business, and enterprises with business problems are not recognised for a long time by the market, and they survive for years. At the same time, other business entities are subject to illiquidity, so the "vicious circle" is not interrupted. Although we can say that effective legal regulations governing payment terms between businesses are in force, it is often violated and bad business entities are not sanctioned. In Bosnia and Herzegovina, in the legislation of entities of the Federation of $\mathrm{BiH}$ and the Republika Srpska entity, a bankruptcy procedure is foreseen for all legal entities that fail to fulfill their financial obligations for more than two months, i.e. have a blocked transaction account for more than two months, with the condition that a creditor starts the process. In practice, this does not happen, creditors after not being paid more than two months out of the agreed deadline, do not initiate bankruptcy proceedings.

Loss above the capital as an item in financial statements is a common occurrence, while in developed countries, the term is unknown. The loss from previous years, which accumulates and reaches and exceeds the total amount of capital, proved that in practice, is not enough reason to quit the company, and this law is not sharply regulated by this problem. So bad companies remain on the market for years and additionally complicate business management and healthy companies.

Stakeholders often lack the right information about the company's business, which additionally complicates the recognition of bad business entities. All companies, micro, small, medium and large are required to produce annual reports. However, the law prescribes the same reports for all companies, which makes it difficult to use the same tools for assessing the continuity of the polling. Micro, small, medium and large enterprises have different characteristics, which also affects the financial indicators obtained from the financial statements. With just a few small businesses, and more middle-sized enterprises, accounting is becoming increasingly important as a function of the company, and financial indicators as predictors of business continuity can be used with greater security. Some authors advocate different forms of financial reports for micro enterprises or for micro and small enterprises.

The gray economy level is significantly lower than in the countries of the developed West, which means that in a certain number of cases official financial data do not represent the state of the enterprise at all. In this way, the total income is shown in a smaller amount, which consequently changes the relations in the financial indicators. Companies prone to such manipulations can further extinguish 
the financial image of the company through reduced profit, if it is desirable to pay less taxes, or greater if it wants to present the situation to the bank or the owner of the capital more beautifully. This all affects the weaker predictive power of financial indicators in transition countries.

In addition, it should be noted that in the sample of treated enterprises, enterprises of different activities were. The author believes that somewhat different results of the research would be that the research was carried out by industries. It is known that the designation of the branch is different in its activity, often by law. As an example, you can take sales revenue that, in accordance with accounting standards, is recorded as income from the core business, and sometimes, for example, discounts in wholesale, booked as extraordinary income. This, of course, also affects financial indicators. Also, for some activities it is necessary to hire a lot of fixed assets, for example, in manufacturing companies, while in some industries the possession of fixed assets is at a minimum, for example, consulting services. All this affects the financial indicators. However, in this study, in the sample taken, division of enterprises by activities would considerably reduce the sample, which would affect the result.

\section{Conclusion}

Although Altman's research has been adapted to predict bankruptcy in developed countries, where the rules of conduct of business entities are more clearly defined and more cumbersome, yet this study has shown that the basics of Altman's method can be modified even for the markets of less-developed countries, but not with a great certainty.There are many studies in the world that have found models and financial indicators that are detectors of financial problems of a company with greater or lesser success. However, similar research is less conducted in the region. In Croatia, Skeljo (2000) conducted a research in which he tested the possibility of using the Altman model. He found that on occasions in which Croatian companies operate, the use of the Altman model did not prove to be a good tool for predicting bankruptcy. He concluded that, due to Croatian market opportunities, possibility of using the Altman model was lower than in the United States.A similar study was conducted by Muminović (2011) in Serbia. He tested the possibility of applying the Altman model to companies whose shares are quoted on the stock exchange. $\mathrm{He}$ cames to the conclusion that Altman's bankruptcy prediction model can not be successfully applied to companies in transition countries.In Bosnia and Herzegovina, Salkić (2013) researched the possibility of applying Altman's and an innovated Altman model for assessing the fulfillment of credit obligations towards banks. She took 40 companies into a sample, and divided them into two groups. The first group consisted of companies that properly fulfill their obligations towards banks, while in the second group there were companies that are late in performing liabilities to banks over 90 days. She came to the conclusion that the 
Altman model as well as the innovated Altman model can not be successfully used in predicting non-fulfillment of obligations towards banks.

This research confirmed that the innovated Altman model can, but with a precautionary dose, also apply to the prediction of bankruptcy of small and medium enterprises in Bosnia and Herzegovina.

Also, this research has shown that there is a gap between the results of research conducted in developed countries and countries in transition, including Bosnia and Herzegovina. Possible reasons are listed in the section Discussion. However, in further scientific work, it is necessary to see whether the countries in transition are still able to compare with developed countries in terms of liquidity and solvency estimation options. It is expected that a greater degree of country development will also increase the likelihood of applying a tool for procedural disturbance business of the country. But researchers just need to prove it.

\section{References}

Altman E.I. (1968). Financial Ratios, Discriminant Analysis and the Prediction of Corporate Bankruptcy, Journal of Finance 23, pp. 189-209.

Altman E.I., Haldeman R.G., Narayanan P. (1977). ZETA Analysis, Journal of Banking and Finance 1, pp. 29-54.

Altman E., Sabato G. (2007). Modelling Credit Risk form SMEs: Evidence from US Market, Abacus. 43 (3), pp. 332-357, URL http://people.stern.nyu.edu[30.12.2014.].

Altman I.E., Sabato G., Wilson N. (2008). The Value of Qualitative Information in SME Risk Menagement, CMRC, Leeds University Business School, UK., URL: http://people.stern.nyu.edu [30.12.2014.].

Beaver, W., (1966). Financial Ratios as Predictors of Failure, Empirical Research in Accounting, Selected Studies, Vol 4, pp. 71-11.

Chancharat N. (2011). SMEs Failure Prediction: Literature Review, ABAC Journal Vol.31 No.3 (September - December 2011) pp.70-81.

Edmister R.O. (1972). Financial Ratios as Discriminant Predictors of Small Business Failure, The Journal of Finance, Vol 27, Issue 1, pp. 129-140.

Ekes K. S., Koloszar L. (2014). The Efficency of Bankruptcy Forecast Models in the Hungarian SME Sector, Journal of Competitiveness, Vol. 6, Issue 2, pp. 56-73.

Janer J. (2011). Bankuptcy Prediction and its Adwentages, Empirical Evidence from SMEs in the French Hospital Industry, Master thesis, Department of Economics, Copenhagen Bussines School, URL : http://studenttheses.cbs.dk/, [30.12.2014.]

Jazdanfar D., Nilsson M. (2008). The Bankruptcy Determinants of Swedish SMEs, Institute form Small Business \& Enterepreneurship, 5-7 November, Belfast, N. Ireland, URL : http://www.diva-portal.org/, [30.12.2014.].

Khanji I. (2010). Failure Predictions for the Small-Medium Enterprises in UK, URL: http://www.academia.edu/, [30.12.2014.].

Marom S., Lussier R.N. (2014). A Business Success Versus Failure Prediction Model for Small Businesses in Israel, Business and Economic Research, Macrothink Institute, Vol 4, No 2, pp. 63-81. 
Kester Dž., Radivojac G. (2015). Analiza rizika insolventnosti kod nefinansijskih kompanijea koje kotiraju na službenom tržištu Banjalučke berze primjenom Altmanobog Z-score modela. X Međunarodni simpouijum o korporativnom upravljanju, pp. 245-258, Banja Vrućica.

www.kralicek.at/pdf/quickbreak [05.01.2018].

Marom S., Lussier R.N. (2014). A Business Success Versus Failure Prediction Model for Small Businesses in Israel, Business and Economic Research, Macrothink Institute, Vol 4, No 2, pp. 63-81.

Muminović S., Pavlović V., Cvijanović J.M. (2011). Predictive Ability of Various Bankruptcy Prediction Z-Score Model for Serbian Publicly Listed Companies, Industrija, Časopis Ekonomskog instituta Beograd, br. 3, pp. 1-12.

Mures-Quintana, Maria-Jesus and Garcia Gallego, Ana. (2012). Proseedings of the First International Conference in Safety and Crises Menagement, in the Constuction, Turism and SME Sectors, USA, Florida, 2012, Credit Risk Assestments: Business Failure in Spanish SMEs Sector, pp. 331-350.

Mramor D., Valenti A. (2003). Forecasting the Liquidity of Very Small Private Companies, Journal of Business Venturing 18, pp. 745-771.

Nur Adiana H.A., Abd Halim A., Rohani M.R., Nasruddin Z. (2014) Modeling Small Business Failures in Malaysia, URL : http://papers.ssrn.com/, [30.12.2014.]

Ohlson, J. A. 1980. Financial Ratios and the Probabilistic Prediction of Bankruptcy. Journal of Accounting Research (spring): pp.109-131.

Petković S. (2010). Mala i srednja preduzeća u funkciji uspješnosti privređivanja (Projektovano na Republiku Srpsku), doktorska disertacija, Banja Luka. Ekonomski fakultet.

Pervan I., Pervan M., Vukoja B. (2011). Prediction of Company Bankruptcy Using Statistical Techniques - Case of Croatia. Croation Operational Research Review, Vol 2, pp. 158-167

Proklin M., Zima J. (2011). Uticaj likvidnosti i solventnosti na poslovanje poduzetnika, Ekonomski vjesnik, Vol. 24 No.1.pp. 72-89.

Salkić A. (2013). Testing of Possibility of Establishing Creditworthiness od Small and Medium Enterprises in Bosnia and Herzegovana by Applying Kralicek DF Indicator, Economic Review - Journal of Economics and Business, Vol. XI, Issue 2, pp.57-70.

Šarlija N., Jeger M. (2011). Comparing financijal distress prediction models before an during recession. Croaton Operational Reaserch Review 2 (1) pp. 133-142.

Škeljo K. (2000). Exploring the possibilities of using the Altman model in Croatian Economics: Master's thesis, Zagreb, Faculty of Economics.

Teti E., Dell'Acqua, Brambilla M. (2012). Bankruptcy Predictors During the Financial Crisis. A Study of Italian SMEs, URL: http://www.mfsociety.org/ [30.12.2014.].

Vidimlić S. (2015). Primjena Chesserovog modela kod predviđanje neispunjenja obaveza prema bankama kod malih preduzeća u Bosni i Hercegovini, Zbornik radova Ekonomskog fakulteta u Sarajevu, pp. 150-166, Sarajevo.

Wellalage N.H., Locke S. (2012). Factors Affecting the Probability of SME Bankruptcy: A Case Study on New Zealand Unlisted Firms. URL: www.ssrn.com [06.01.2015.].

Mikerević, D.J. (2011). Finansijski menadžment, četvrto izmijenjeno i dopunjeno izdanje, Banja Luka. Ekonomski fakultet, Finrar.

Soldić-Aleksić J., Hroneos Krasavac B. (2009). Kvantitativne tehnike u istraživanju tržišta, Primjena SPSS računarskog paketa, Beograd, Centar za izdavačku djelatnost Ekonomskog fakulteta u Beogradu. 


\section{INOVIRANI ALTMANOV MODEL KAO PREDIKTOR NARUŠENOSTI POSLOVANJA MALIH I SREDNJIH PREDUZEĆA U BOSNI I HERCEGOVINI}

Apstrakt: Istraživanje je izvršeno sa ciljem pronalaska modela koji će najbolje predvideti finansijski uspeh ili neuspeh preduzeća. Na uzorku od 392 malih i srednjih preduzeća u Bosni i Hercegovini vršena su testiranja mogućnosti primene inoviranog Altmanovog modela za predviđanje finansijskih teškoća preduzeća. Posmatrani su finansijski izveštaji ovih preduzeća iz 2014. godine. Uzorak je podeljen $\mathrm{u}$ dve grupe: preduzeća koja su imala blokirane transakcijske račune tokom 2015. i 2016. godine i ona preduzeća koja nisu imala blokade transakcijskih računa tokom ovog perioda. Testiranje je pokazalo da se Altamnov model može, ali sa ograničenom mogućnošću, primeniti za predviđanje narušenosti poslovanja malih i srednjih preduzeća $u$ Bosni i Hercegovini. U radu su prezentovane činjenice koje utiču na poslovanje malih i srednjih preduzeća u Bosni i Hercegovini, te način na koji utiču na odabir i eventualno drugih prediktora neupešnog poslovanja.

Ključne reči: predviđanje, mala i srednja preduzeća, Altmanov model, finansijski neuspeh, narušenost poslovanja, finansijski pokazatelji.

\section{Author's biography}

Selma Vidimlić has been employed as a director in the public company "Tržnica" Zenica since 2017. Previously he has been a member of the banking sector in NLB Bank as a regional director, since 2009, earlier in Raiffreisen Bank as a regional director of retail jobs, since 2005, and also earlier, from 2001 also in the bank. She graduated from the Faculty of Economics at the University of Sarajevo, Department of Business Economics and obtained a master degree from the Faculty of Economics at the University of Sarajevo, defending the thesis "The Prerequisites and Limits of Risk and Capital Management on the Capital Market of Bosnia and Herzegovina". She is also a $\mathrm{PhD}$ candidate. Her doctoral dissertation is entitled "Selection of Financial Indicators in Function of Early Warning on Financial Impacts of Enterprises" at the Faculty of Economics of the University of Banja Luka. 